\title{
LEARNING DEMAND AND CLASSROOM DISCOURSE DESIGN TOOLS TO IMPROVE STUDENTS' CONCEPTUAL UNDERSTANDING OF THE NATURE OF ELECTROLYTES
}

\author{
Nur Jahan Ahmad ${ }^{1 *}$, Nor Asniza Ishak ${ }^{1}$ and Muhammad Abdul Hadi Bunyamin ${ }^{2}$ \\ ${ }^{1}$ School of Educational Studies, Universiti Sains Malaysia, 11800 USM Pulau Pinang, \\ Malaysia \\ ${ }^{2}$ School of Education, Faculty of Social Sciences and Humanities, Universiti Teknologi \\ Malaysia, 81310 Skudai, Johor, Malaysia \\ *Corresponding author: jahan@usm.my
}

Publication date: 24 December 2019

To cite this article: Nur Jahan Ahmad, Nor Asniza Ishak, \& Muhammad Abdul Hadi Bunyamin. (2019). Learning demand and classroom discourse design tools to improve students' conceptual understanding of the nature of electrolytes. Asia Pacific Journal of Educators and Education, 34, 187-218. https://oi.org/10.21315/apjee2019.34.10

To link to this article: https://doi.org/10.21315/apjee2019.34.10

\begin{abstract}
This paper reports on two design tools used in a teaching sequence (module) based on the Leeds Model Framework. This model framework draws upon theoretical insights into perspectives on learning and empirical studies to improve the teaching of electrochemistry by using the learning demand and the communicative approach. The learning demand identifies the differences between everyday social language and the school scientific language in terms of both content and the nature of the knowledge that are used to represent the same phenomena. The communicative approach focuses on the classroom discourse, especially on how the teacher interacts with the students when new ideas are introduced on the social plane of the classroom. These two design tools present the fundamental guidelines that could be utilised in designing a teaching sequence to improve students' conceptual understanding in any specific learning of science content. A study on two intact groups that had similar academic ability was carried out. The experimental class was conducted using the design teaching whilst the baseline group (comparison group) had followed the normal classroom teaching. The students' conceptual understanding in both classes was tested using a post-diagnostic test. The evaluation of students' responses of the items in the post diagnostic test was carried out using the ideographic and nomothetic approaches. The results show that there were significant differences in the experimental students' performances in comparison to the students in the baseline group. The findings suggest that the learning demand and different types of discourses had enabled students to explain some aspects of electrolytic cell content in details. The experimental students
\end{abstract}


had demonstrated better conceptual scientific understanding than the baseline group in the learning area concerning the nature of electrolytes in the electrolytic cell.

Keywords: classroom discourse, electrochemistry, electrolytic cell, social constructivism

\section{INTRODUCTION}

The goal of learning science is for students to engage in science practices as they use their scientific understanding of the core ideas and concepts to make sense of phenomena or solve problems by applying the concept and theory of science. According to the constructivist view, the individual perspective on learning basically focuses on how the individual develops his or her thinking and understanding. Many of the built-up theories are attributed to the work of Piaget, who argues that individuals construct knowledge based on their experiences with their external surroundings. According to Driver, Asoko, Leach, Mortimer and Scott (1994), the constructivist view suggests that knowledge is not transmitted directly from one person to another but is actively developed and constructed by the learners. Thus, the fundamental principle of constructivism is that learners create or construct new understanding by actively building and connecting previous knowledge and experiences (Schunk, 2000). The learners are believed to create meaning as inner representations based upon their own experiences, rather than from other external means of sources.

Vygotsky (1978) mentions that in a classroom teaching, following the social constructivist perspective, the teacher introduces the social language of science (scientific view) on the social plane of the classroom and these ideas are discussed and communicated between the individuals (teacher-student \& student-student); language and other semiotic mechanisms (e.g. diagrams, symbols, gesture) that provide the tools for individual thinking (Leach, Ametller, \& Scott, 2010). This is where the content of science is being introduced to the language of the scientific community. Furthermore, students often tend to explain scientific events in their own words in order to clarify meaning according to their own perspective and understanding; in other words, by using their own social language that is different from the language of school science. In addition, the role of the teacher is closely associated with the content of the teaching from the social constructivist perspective (Kabapinar, 2009; Kabapinar, Leach, \& Scott, 2004), in which the teacher is the agent who introduces the new language of school science (the scientific view). The teacher also plays an important role to detect students' starting points (students' everyday social language) so that their common mistakes can be tackled during the interactions between the individual with the teacher and others before the 
individual could try to make sense of what he or she has learned through the process of internalisation, as described by Vygotsky.

Teaching chemistry has often posed a great challenge to the teachers, as it involves macroscopic, microscopic and symbolic entities. The findings from the literature (summarised below) show that students have difficulties in electrochemistry topic for the areas mentioned (Marais, 2011; Ogude \& Bradley, 1994; Rollnick \& Mavhunga, 2014):

1. The roles of ions in the conductivity of the electrochemical cell (this also related to the migrations of ions to the electrodes)

2. The chemical formulae and equations

3. The electrode terminology that relates to the structure of the electrochemical cells

4. The chemical processes and reactions involved in the electrochemical cells with some descriptions on the differences in the electrolytic and voltaic cells

5. Redox reactions in electrochemistry

In relation to the difficult topics in electrochemistry, there are many studies on designing, implementing and evaluating teaching in order to improve students' conceptual understanding and difficulties in the area of science either on general topic or a specific content, with the aim of improving teaching and learning of science (Acar \& Tarhan, 2007; De Jong, Acampo, \& Verdonk, 1995; Garnett \& Treagust, 1992a; Ringnes, 1995; Rosenthal \& Sanger, 2012). There are many different frameworks that are reported in the literature that present the approach of designing a teaching at general level or specific content. Some of these approaches are similar with each other or different in their own ways depending upon the structure of the design (Buty, Tiberghien, \& Le Maréchal, 2004; Leach, Scott, Ametller, Hind, \& Lewis, 2006; Scott, Leach, Hind, \& Lewis, 2006). The literature has reported that there are many approaches that are used by educators to enhance students' understanding in electrochemistry (Hawkins \& Phelps, 2013; Onder, 2017; Özmen, 2007). One example of teaching chemistry is by using animated video or software to visualise the movement of electrons and ions. For example, a study by $\mathrm{Su}$ (2018) shows that students' innovative and problem-solving skills were enhanced when animated concept mapping was utilised in addition to collaborative reasoning among the students in groups; i.e. when the students collaborated and discussed with each other. 
Researchers in classroom discourse have long been suggesting the importance of classroom discourse in scientific meaning making processes (Michaels \& O'Connor, 2015; Mortimer \& Scott, 2003). For students to talk real science in the classroom, the teachers' initiative to encourage the classroom discourse is very crucial. Also, the teachers must alter their classroom discourse in order to introduce the language of school science (scientific concepts and theories). Therefore, the classroom discourse is developed by the teacher with an aim to explain activities, give direction, provide feedback or to check students' understanding (Mercer \& Dawes, 2014; Tytler \& Aranda, 2015). Also, science learning is enacted in classrooms largely through the interactions between teachers-students, studentsstudents, student-materials, and teacher-materials.

The main purpose of this study, also as discussed above, was to examine how the design tools were utilised by the teacher in the classroom (on social plane) to ensure that the scientific information was conveyed and understood. Following this, the students conceptual understanding was analysed based on the responses in the post-diagnostic test and a selected classroom observation. There were two main objectives of this study; namely: (i) to determine the experimental students' conceptual understanding in some aspects of electrochemistry after the teacher had utilised the design tool (learning demand) in comparison with the baseline group who had followed the normal classroom teaching, and (ii) to examine the experimental students' conceptual understanding in of some aspects of electrochemistry after the teacher had utilised the design tool (communicative approach).

\section{LITERATURE REVIEW}

\section{Students' Difficulties in Electrochemistry}

A review of the literature by several researchers have shown that students have difficulties in understanding the concepts of oxidation and reduction over time (Allsop \& George, 1982; Brandriet \& Bretz, 2014; Su, 2018). Students and teachers often consider electrochemistry and related subjects as one of the most difficult topics in chemistry (Marais, 2011). The topic of electrochemistry focuses on chemical reactions, which produce an electric current and use an electric current to drive chemical reactions. Secondary school students often find that voltaic/ galvanic cells and electrolytic cells are very difficult to understand since these topics involve concepts about electricity and oxidation-reduction, both of which are very challenging (Doymus, Karacop, \& Simsek, 2010). Students who have learned the topic of 'electricity' in Physics understand that current flows in a closed circuit; however, the electric current in chemistry is depicted not just as the flow of 
electrons in the circuit but also the flow of ions in the solution (Garnett, Garnett, \& Hackling, 1995; Garnett, Garnett, \& Treagust, 1990). Garnett and Treagust (1992b) in their study found that students studying both physics and chemistry were confused about the nature of electric current in both metallic conductors and electrolytes because they did not understand the relationship between these two elements in the electrochemical cells. In Huddle, White, and Rogers, (2000) and Garnett et al. (1995), the students tend to believe that current was always involved with movement of electrons, even in solution and through the salt bridge.

Furthermore, electrochemistry is related to oxidation and reduction processes that makes it a difficult concept to comprehend (Brandriet \& Bretz, 2014). The conceptual difficulties in explaining the redox reactions are mainly in the subjects of electron transfer in oxidation and reduction that occur spontaneously, and student's failure to remember the oxidation number (De Jong et al., 1995; Garnett \& Treagust, 1992a; Posner, Strike, Hewson, \& Gertzog, 1982). Furthermore, students have many alternative conceptions about oxidation and reduction are the foundations of electrochemistry, as the students may have different learning experiences during their first encounters with the topic of redox; for example, in the macroscopic, microscopic, symbolic and/or algebraic systems of representation (Harrison \& Treagust, 1998). The difficulties that students encounter in terms of redox is related to the process and it is also conceptual. However, recent literature regarding the topic of electrochemistry is insufficient in addressing the issue on overcoming the difficulties in learning this topic because students fail to make connections of new knowledge gained to their existing knowledge.

\section{Classroom Discourse in Science Teaching and Learning}

The 21st century learning skills have emphasised on critical thinking, creativity, collaboration, and communication skills (4 Cs). Additionally, Lee, Quinn, and Valdés (2013) highlight the pressing need for teachers' science lessons to focus on the language-rich aspects of scientific inquiry and communication for all students that are embedded in scientific practices. In the classroom, collaboration and communication skills are essential components as the students need to reach out and collaborate with their peers and teachers. Thus, using language to mediate the situation, classroom discourse should be encouraged in the 21 st century teaching and learning.

Classroom discourse is described in many versions with similar purpose which is to develop students' communicative skills in science learning (Cazden, 2001; Cazden \& Beck, 2003; Schegloff, 1978; Lemke, 1990; Mortimer \& Scott, 2003; Scott, Mortimer, \& Aguiar, 2006). Iksan and Daniel (2015) mention that verbal 
questioning techniques are crucial in teaching and learning science. They find that the types of teachers' verbal questions when teaching electrochemistry can be categorised into content and management questions. This is how they link the questioning techniques to get the content from the students; in addition, to motivate students to get involved in the classroom discussions.

With a high value placed upon both scientific knowledge and practices, all students need is a teacher who can provide meaningful, authentic, and rigorous opportunities to learn science (Lewis, Baker, \& Helding, 2015). Furthermore, the opportunities for students to talk science and how the learning instructions is designed also influence the access to scientific thinking skills (Lemke, 1990). Hence, to provide opportunities for students to learn to develop logical scientific arguments, the reform in science education classroom pedagogy should be focusing on the socio-communicative nature of the classroom (Driver et al., 1994; Tobin, 1993). Nonetheless, the literature in classroom discourse in the context of science is still lacking because teachers often use authoritative discourses (Mortimer \& Scott, 2003) in their teaching to ensure students understand the scientific information conveyed.

\section{Social Perspectives on Theory of Learning}

Students' everyday language use is different from the scientific point of view. Students often describe 'energy' as something like 'I'm tired because I don't have energy', whilst in scientific explanation, 'energy' can be described as 'chemical energy', 'potential energy' and so forth. Thus, there are differences between students' everyday language and the language of school science. These differences have been described further by Vygostky, who distinguishes 'spontaneous' everyday concepts (from day-to-day interactions) and 'scientific' concepts (formal concepts originated in a particular discipline). Spontaneous everyday concepts are distinguished as concepts that are learned without conscious attention through daily interaction, whilst scientific concepts are those formal concepts that are founded in a particular discipline or a body of knowledge. Vygotsky is also interested in the development of individual cognitive skills but he describes it within the instructional context and this life long process of development is influenced by the social interaction which leads to the cognitive development (Forman \& Kraker, 1985). Thus, Vygotsky (1978) postulates that learning involves a movement from a social plane (e.g. classroom discussions) to the personal plane of the individual (inner self). This is very important as the teacher is mediating the teaching and learning following the socio-cultural perspective. 
Wertsch and Tulviste (1992) have further stated that the Vygotskian view is limited as there is no recognition of the different form of intermental functioning that occur on the social plane. Thus, they claim that additional tools are needed to develop the Vygotskian account. From the work of Bakhtin (1934), who claims that different modes of discourse such as dialogue (Salloum \& BouJaoude, 2019) are used in the society that is known as 'social languages' (Leach \& Scott, 2003). The social language of science is different from everyday ways of talking and thinking about the natural phenomena because it involves explaining the scientific phenomena based on the accepted scientific explanation. For example, 'neutralisation is the reaction between acid and base and produces salt'; while in everyday way of talking, students might say that 'the product of neutralisation is a neutral solution' which leads to a misconception (Schmidt, 1991).

Hence, when the scientific ideas are introduced by the teachers in the social plane of the classroom, the students are learning to talk in the formal language of science. This specific knowledge gained by interactions is through the process of internalisation where the emphasis is on the language a tool for individual thinking (Jones, 1998; Leach \& Scott, 2003; Scott, Leach, et al., 2006; Shemwell \& Furtak, 2010). Then, after the individual is able to reflect and make individual sense of what being communicated, it is transferred to the individual plane through the process of internalisation. Wertsch (1985) also describes how our culture has influenced in 'patterning' our social languages and speech genres. Thus, a shift from social to personal plane of an individual is influenced by the culture where the student is in, and the student is moving from one culture (everyday) to another (science), and that the teacher has a role in inducting students into science culture or enculturating them.

\section{Leeds Model Framework}

The Leeds Model framework is informed at a large grain size by the 'socialconstructivist' theoretical framing perspective. This framework is appropriate for this study because the design of the teaching is also informed at a fine grain size by the design tools that are used in the classroom teaching such as the learning demands and the communicative approaches. The conceptual framework of this study is presented in Figure 1 and the aspects of learning demand and communicative approach are discussed in this paper. 


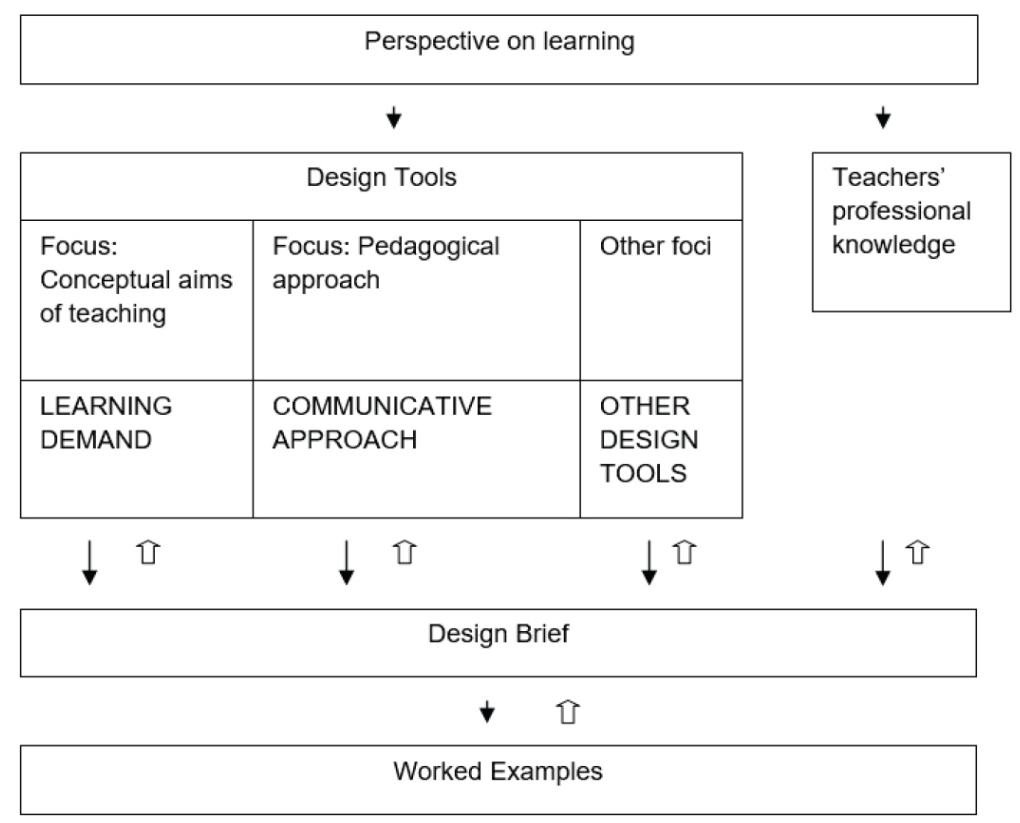

Figure 1. A research evidence informed approach to designing science teaching (Ametller, Leach, \& Scott, 2007)

In Figure 1, Ametller, Leach and Scott (2007, p.483) explain that the term 'design tool' refers to 'the concepts which draw upon theoretical perspectives on teaching and learning, and the products of empirical research on teaching and learning, to inform decisions about the design of teaching'. The use of notion the learning demand addresses the differences between students' everyday knowledge and the scientific knowledge, and this learning demand is linked to the classroom discourse, which is the communicative approach that is used on the social plane for student-teacher and student-student interaction in the classroom.

\section{The Learning Demand Tool}

As there are differences between everyday language and scientific ways of knowing in terms of both content and nature of the knowledge used to represent the same phenomena, different kinds of intellectual demand are created; thus, the extent of these differences in everyday language and social language of science is referred to as the 'learning demands' (Leach \& Scott, 2002; 2003; 2008). Leach and Scott (2008) posit that the concept of learning demand itself is drawn upon the social constructivist view, in which students' everyday social language is identified 
and compared with the social language of school science (scientific theory and concept). Furthermore, students' everyday reasoning provides the starting point for thinking about the design of the teaching sequence. Leach and Scott (2003) claim that the bigger the learning demands, the more the challenge for teachers to assist students to make sense of the scientific theories or concepts. The learning demand is used to challenge students in their existing beliefs about a particular scientific matter. Thus, the teachers must be able to predict the learning demands associated with the differences between students' ideas and scientific view. In Leach et al. (2010), the learning demands are content specific and the specified teaching goals are developed to address the learning demands.

\section{The Communicative Approach}

Building upon the works of Bakhtin (1934) and Vygotsky (1978), Mortimer and Scott (2003) develop a framework to characterise discourse in science classrooms as shown in Table 1. They use two dimensions to define how teachers and students communicate: (i) interactive/non-interactive and (ii) dialogic/authoritative. Acknowledging the underlying dialogic nature of the interaction (Bakhtin, 1981), Mortimer and Scott (2003) distinguish between authoritative discourse and dialogic discourse, in the former, teacher's purpose is to focus students' attention only on one idea, such as, to present scientific information; whereas the latter is a range of ideas that are communicated and considered. The Leeds Model framework thus advocates the communicative approach as a design tool that focuses on classroom discourse, specifically on how the teacher interacts with students when new ideas are introduced on the social plane of the classroom.

Table 1. Four classes of the communicative approach

\begin{tabular}{|c|c|c|}
\hline & Interactive & Non-interactive \\
\hline Dialogic & $\begin{array}{l}\text { A: Interactive/Dialogic } \\
\text { The teacher seeks to elicit and } \\
\text { explore students' ideas about an issue } \\
\text { with a series of 'genuine' questions. }\end{array}$ & $\begin{array}{l}\text { B: Non-interactive/Dialogic } \\
\text { The teacher is in presentational mode } \\
\text { (non-interactive), but explicitly } \\
\text { considers and draws attention to } \\
\text { different points of views (dialogic), } \\
\text { possibly in providing a summary of an } \\
\text { earlier discussion. }\end{array}$ \\
\hline Authoritative & $\begin{array}{l}\text { C: Interactive/Authoritative } \\
\text { The teacher is typically leading } \\
\text { the students through a sequence of } \\
\text { instructional questions and answers } \\
\text { with the aim of reaching one specific } \\
\text { point of view. }\end{array}$ & $\begin{array}{l}\text { D: Non-interactive/Authoritative } \\
\text { The teacher presents a specific point } \\
\text { of view. }\end{array}$ \\
\hline
\end{tabular}

(Mortimer \& Scott, 2003; p. 35) 


\section{The dialogic and authoritative dimensions}

According to Mortimer and Scott (2003), interactive 'dialogic' version, is meant for the teacher to explore students' ideas from their point of views, and students' opinions are taken into account. On the opposite, if the teacher only seeks students' ideas from the scientific point of view, which is more on the scientific content, then it is an 'authoritative' communicative approach.

\section{The interactive and non-interactive dimensions}

Mortimer and Scott (2003) further describe that the dialogic and authoritative communicative approaches can be either interactive or non-interactive dimensions, depending upon the number of participations. It is 'interactive' when the students participate and there is two-way communication either with the teacher or their peers. However, it is non-interactive if only the teachers present the points of view and it is a one-way communication.

\section{Interactive dialogic discourse}

Scott, Mortimer, et al. (2006) describe that an 'interactive/dialogic' discourse allows the teacher to find out students' everyday views about a particular phenomenon and this talk is open to different views and perspectives. For example, the teacher may ask students to describe what they think of 'electricity', and there are a range of ideas from students that can be explored. The conversation could be anything that is related to the students' everyday life.

\section{Non-interactive dialogic discourse}

In a 'non-interactive dialogic', the teacher summarises the students' different points of view from the interactive dialogic discourse. For instance, a teacher's summary of students' responses could be: 'Ana thought that electricity is created when the battery is used whilst Danish thought that electricity is a flow of current'.

\section{Interactive authoritative discourse}

When the purpose of the classroom discourse is to obtain what the students have to say from the scientific point of view, it is described as 'interactive/authoritative' discourse. For example, the teacher asks students the question like: 'What kinds of ions are present in copper (II) sulphate solution?' From this question, the teacher may expect students to provide answers like: 'copper and sulphate ions', which is 
the answer based on the scientific point of view and not like general answers as in the 'interactive/dialogic' discourse.

\section{Non-interactive authoritative discourse}

In another case, when the teacher is going to present the scientific point of view where there is no room for discussions between the teacher and students, a "non/ interactive-authoritative' discourse is used. For example, the teacher presents the scientific view of an electrolyte. At this point, the authoritative discourse does not allow any exploration of ideas or any discussions, as the teacher is presenting the scientific knowledge in order to reshape the students' ideas if they are found to be inconsistent with the scientific ones.

In this study, the students are exposed to different types of classroom discourse described above. The following section presents the methodology of the research.

\section{METHODOLOGY}

This study had utilised a research design with both quantitative and qualitative approaches within the interpretive paradigm. A case study using a pre-experimental design using post-test only with non-equivalent group was conducted in order to achieve the objectives of this study (Creswell, 2015). The teaching sequence (module) was designed and it was implemented in the experimental class. A baseline group was selected as a comparison group. Both groups were given the post diagnostic test after the completion of the topics. Only the post test was given to the students because the content of the topics was not introduced; meaning that the students learnt new scientific information such as the structure of electrolytic cell and the half equation. The students in the baseline group had followed the normal teaching classroom such as lectures (using talk and chalk/PowerPoint slides); and they also carried out the experiment according to the text book.

\section{Samples}

\section{Experimental and comparison classes}

The subjects in this study were two classes of Form 4 students (average age of 16) with a similar academic ability. The intervention was conducted in one class (experimental class) with 37 students whilst the baseline class comprised of 27 students who followed the normal classroom teaching. These two intact groups of students studied in the same school. The school had four science classes and 
two groups were found to be similar in terms of their academic ability (based on the national examination) and hence, these two groups were selected. The teacher in the baseline group also had similar academic background and experiences in teaching chemistry with the teacher in the experimental class, and both teachers had allowed the teachings to be video recorded. Even though the numbers of students were not the same but the aspects such as students' similar academic ability, teacher's similar academic qualification and years of experiences in these two intact groups were reasonable to get plausible results. Also, the responses in the post diagnostic test were analysed using interpretive paradigm and were coded accordingly. The teacher in the experimental class used the teaching sequence (module), and utilised the suggested questions using different types of discourses. The topic selected was specifically on electrolytic cell. The learning objectives and outcomes were in accordance to the chemistry syllabus. After an interventaion of eight weeks, the students in both classes were given a post-diagnostic test in an open-ended format.

\section{Data Analysis}

The analysis of the items was conducted using the ideographic approach, and was followed by the nomothetic approach (Driver \& Easley, 1978). The students' ideas and understanding on some aspects of electrochemistry after they had been taught the topic were gathered, in which the items were designed as more conceptually, phenomenologically or used both framing approaches. The reasoning was based on macroscopic, microscopic and symbolic entities. The response such as 'Student understood that there is a flow of electricity in the wire that makes it possible to light up the bulb' did not contain the taught key features; i.e., 'this is because electrons move in the wire from the anode to the cathode'. Thus, this response was analysed ideographically. However, as this response was coded as partially correct, this is a nomothetic analysis. There are four types of categories (set) were developed, which were "Scientifically correct" (SC), "Partially correct" (PC), "Other" $(\mathrm{O})$ and "Not attempted" (NA). The students" responses were analysed using descriptive analysis and Chi-square test of independence for the comparison and experimental classes.

\section{Inter-Rater Reliability Agreement}

In order to determine the degree of agreement on the developed coding schemes, the inter-rater reliability was performed by the researcher and a professor in Science Education. According to Silverman (1997), inter-rater reliability involves "giving the same data to a number of analysts (or raters) and asking them to analyse it according to an agreed set of categories" (p. 148). Then, the reports are examined 
and any differences in the findings are discussed and ruled out. For this study, the professor had reviewed one class of students selected randomly by the researcher and there were 27 students in the class. The developed coding schemes were referred and both the results for the SC, PC, O and NA responses were compared. Out of 27 students times 25 items that were equal to 675 responses, only 17 responses were found to be not compromised with both the researcher and the professor and counted as $2.5 \%$, meaning that the degree of agreement is about $97.5 \%$.

\section{The Content Area in the Diagnostic Test}

The content area in the diagnostic test were as follows:

1. The nature of electrolyte

2. The movement of ions

3. The half-cell equation

4. The conductivity in electrolytic and voltaic cell

5. The reactions at the electrodes

There were 25 items in the post diagnostic test. For this study, only one content area (five items) which is the nature of electrolyte (Items 1a-e) that was discussed. From the pilot data, the reliability testing was analysed using SPSS and the Cronbach Alpha coefficient of the research instrument was 0.905 . The content of the items constructs (five content areas) was reviewed by two science education professors at the university and one teacher at a school. Only the coding of 'scientifically correct' is discussed due to large data from the findings in all content area. The examples of the items are in Appendix A. The microscopic entity is discussed in this findings as students often have difficulties in this aspect.

\section{RESULTS}

The responses in the post diagnostic test of the experimental (37 students) and comparison (27 students) groups were compared. In this case, to compare how much better the experimental class had performed based on their 'scientifically correct' answer in comparison to the performance of students in the comparison class, and vice versa. Thus, a Chi-squared test for independence $\left(\chi^{2}\right)$ was used to compare the association between two categorical variables, in this case the variables of 'scientifically correct' answer against 'other than correct' (partially correct, other and non-attempted). As some of the individual items had less than 5 responses; thus, a $2 \times 2$ table was used as this gave more accurate results obtained 
from Fisher's Exact Test. The values were used to evaluate the significance difference between the experimental class and the comparison class performance in the post diagnostic test.

The number of 'scientifically correct' answers and 'other than correct' were computed in $2 \times 2$ contingency table using SPSS programme. The degree of freedom is $1(\mathrm{df}=1)$ and the critical values used are mentioned below:

$$
\begin{aligned}
& \alpha=0.05, \chi^{2}=3.84, \\
& \alpha=0.02, \chi^{2}=5.41, \\
& \alpha=0.01, \chi^{2}=6.64, \text { or } \\
& \alpha=0.001, \chi^{2}=10.83
\end{aligned}
$$

\section{The Learning Demand}

For the first objective, which is to determine the experimental students' conceptual understanding of some aspects of electrochemistry after the teacher had utilised the design tool (learning demand) in comparison with other group who followed a normal classroom teaching, the results are presented according to Item 1a-e in the post-diagnostic tests.

\section{The Nature and Properties of Electrolytes (Items 1a-e)}

Following the insights gained from the analysis of students' ideas in some aspects of electrochemistry, the analysis of the curriculum, text book, practical book, reference book, and some of the responses in the piloted post diagnostic question, the learning demand is identified in order to conceptualise the differences in students' view of the concepts involved in electrochemistry and the scientific views following teaching. For this objective the learning demand is "to understand the role of electrolytes (ions) and electrons in the conductivity of the electrolytic cell."

From the results shown in Table 2, there were significant differences between the number of correct responses of the experimental and comparison groups relating to the nature and properties of electrolyte for items $1 \mathrm{a}, 1 \mathrm{~b}, 1 \mathrm{c}$ and $1 \mathrm{e}$; meaning that more students in the experimental class were able to answer correctly compared to the comparison class. Even though there was no significant difference for item 1d, 
it still shows that about $18 \%$ more students in the experimental class had performed better than the baseline class.

Table 2. Chi-squared results for items 1a-e

\begin{tabular}{|c|c|c|c|c|c|c|c|c|c|}
\hline \multirow[b]{2}{*}{ Question } & \multicolumn{2}{|c|}{ Exp } & \multicolumn{2}{|c|}{$\mathrm{B} 1$} & \multirow{2}{*}{$\begin{array}{l}\text { Chi- } \\
\text { squared } \\
\left(\chi^{2}\right)\end{array}$} & \multirow[b]{2}{*}{$\begin{array}{l}\text { Probability } \\
(\rho)\end{array}$} & \multirow{2}{*}{$\begin{array}{c}\text { Fisher } \\
\text { Exact } \\
\text { Test }\end{array}$} & \multirow{2}{*}{$\begin{array}{c}\text { Chi- } \\
\text { squared } \\
\text { critical } \\
\left(\chi^{2}\right)\end{array}$} & \multirow[b]{2}{*}{$\begin{array}{c}\alpha \\
\text { (critical) }\end{array}$} \\
\hline & Correct & $\%$ & Correct & $\%$ & & & & & \\
\hline $1 \mathrm{a}$ & 26 & 70.3 & 8 & 29.6 & 10.35 & 0.001 & 0.002 & 6.64 & 0.01 \\
\hline $1 b$ & 30 & 81.1 & 6 & 22.2 & 21.97 & 0.000 & 0.000 & 10.83 & 0.001 \\
\hline $1 \mathrm{c}$ & 29 & 78.4 & 5 & 18.5 & 22.46 & 0.000 & 0.000 & 10.83 & 0.001 \\
\hline $1 d$ & 19 & 51.4 & 9 & 33.3 & 2.06 & 0.151 & 0.204 & 3.84 & 0.05 \\
\hline $1 \mathrm{e}$ & 15 & 40.5 & 4 & 14.8 & 4.95 & 0.026 & 0.030 & 3.84 & 0.05 \\
\hline
\end{tabular}

\section{Students' Conceptual Understanding for Item 1a}

\section{Responses referring to "the presence of freely moving ions"}

In item 1a, students had to explain that in an aqueous state, the bulb lights up because of "the presence of freely moving ions", but not just because the substance is an "electrolyte". For item 1c, similar to item 1a, the students also had to explain that in a molten state, the bulb lights up because of "the presence of freely moving ions". This was accepted as a "scientifically correct" answer.

In Table 2, for item 1a, there was a significant difference between the number of correct responses of experiment and comparison classes relating to the nature and properties of electrolytes $\left(\chi^{2}=10.35, \mathrm{df}=1, \rho=0.001\right)$. The critical value of Chisquared for $\mathrm{df}=1$ and $\alpha=0.01$ was 6.64 . The obtained value of $\chi^{2}=10.35$ from Table 2 was larger than the critical value of $\chi^{2}=6.64$. Also, the $\rho$ value of 0.001 was smaller than $\alpha=0.01$, meaning that the difference between the classes was significant at the $1 \%$ level. For item $1 \mathrm{c}$, the interpretation of the Chi-squared value is not presented because the content of question in item 1a and $1 \mathrm{c}$ require similar kind of answer (aqueous and molten electrolyte in 1a and 1c, respectively).

From the responses, there was a similar pattern for those students in the experimental class who had answered correctly (26 students), in which most of them could explain about the presence of freely moving ions in aqueous substance $\mathrm{X}$ that make it able to light up the bulb; in comparison to the baseline class, only eight students were able to describe such phenomena. There were also differences in terms of the 
structure of answers presented in which most students in the experimental class were able to describe better scientific explanation compared to the comparison class as shown below:

"I think the aqueous allows the bulb to light up because the ions that is anion and cation move to anode and cathode respectively. This will cause freely moving electrons in the circuit and will produce electric current" [Exp-1]

"In aqueous $\mathrm{X}$, there is freely moving ions of substance X. The freely moving ions allow the electricity to flow. Therefore, the circuit is complete. So, the bulb will light up" [Exp-t]

In comparison to the baseline class, the structures of the answers were more direct and simple as shown below:

"They are freely moving ions in aqueous $\mathrm{X}$ “ $[\mathrm{B} 1-\mathrm{a}]$

"There are freely moving ions" [Bl-h]

Thus, the results indicate that the students in the experimental class had demonstrated better scientific conceptual understanding than the baseline group in terms of their ability to describe the sub-microscopic phenomena in the electrolyte.

\section{Students' Conceptual Understanding for Item 1b}

\section{Responses referring to 'the ions are fixed in lattice position' or 'the ions do not move freely'}

Item $1 \mathrm{~b}$ required the students to explain the reason why the bulb did not light up when the substance was in solid state. From Table 2, there was a significant difference between the number of correct responses of experiment and comparison classes relating to the nature and properties of electrolyte $\left(\chi^{2}=21.97\right.$, $\mathrm{df}=1$, $\rho=0.000)$. The critical value of Chi-squared for $\mathrm{df}=1$ and $\alpha=0.001$ was 10.83 . The obtained value of $\chi^{2}=21.97$ was larger than the critical value of $\chi^{2}=10.83$. Also, the $\rho$ value of 0.000 was smaller than $\alpha=0.001$; thus, the obtained Chisquared value was significant; meaning that the difference between the classes was significant at the $0.1 \%$ level.

Furthermore, in item $1 \mathrm{~b}, 81.1 \%$ of students in the experimental class were able to answer correctly, compared to only $22.2 \%$ in the comparison class. These results 
suggest that students who had followed the teaching sequence were $58.9 \%$ more likely than those in the baseline class to explain that without the presence of freely moving ions in the solid state, the bulb was not light up as the electricity was not produced. Similar observations were found in the structure of the answers for the experimental class where the responses were more precise and in depth, compared to the baseline class. Such responses are stated below:

\section{(Experimental class)}

"The solid X particles are fixed in position. So they cannot move freely to the positive and negative terminal and no electron moves around the circuit as a result. Therefore, the bulb cannot light up" [Exp-o]

\section{(Baseline class)}

"The ions is not moving" [B1-a]

The above examples demonstrated that students in the experimental class had better conceptual understanding in describing the sub-microscopic phenomena compared to the baseline class. This also indicates that students in the experimental class were more confident in answering the questions and able to describe further regarding what happens in the wire even though the question does not require them to do so. Thus, the way the teacher posed the questions to the students is crucial as to encourage them to be involved in the discussions. As reported in Lewis et al. (2015), they mention that the classroom discourse provides the opportunity for the students to engage in a meaningful learning. From this finding, it can be concluded that students in the experimental class had better conceptual understanding in explaining that when electrolyte is in solid state, the ions were not able to move thus the bulb it not light up (30 students in the experimental class and only six (6) students in the baseline class who were able to answer correctly).

\section{Students' Conceptual Understanding for Item 1d}

\section{Referring to 'substance $Y$ is a covalent compound' or 'substance $Y$ is an electrolyte'}

For item $1 \mathrm{~d}$, there was no significant difference between the number of correct responses of experiment and comparison classes relating to the nature and properties of non-electrolytes $\left(\chi^{2}=2.06, \mathrm{df}=1, \rho=0.151\right)$. From Table 2 , the critical value of Chi-squared for $\mathrm{df}=1$ and $\alpha=0.05$ was 3.84. The obtained value of $\chi^{2}=2.06$ was 
smaller than the critical value of $\chi^{2}=3.84$. Also, the $\rho$ value of 0.151 was bigger than $\alpha=0.05$, thus the obtained Chi-squared value was not significant; meaning that there was no significant difference between the number of correct responses of experiment and comparison classes relating to the nature and properties of nonelectrolytes in item $1 \mathrm{~d}$.

In this item, $51.4 \%$ students in the experimental group were able to answer correctly, compared to $33.3 \%$ in the comparison class. The results suggest that there was no significant difference between the number of correct responses of the experimental and comparison groups relating to properties of non-electrolytes. However, the results also suggest that students following the designed teaching sequence were $18.1 \%$ more likely than those following the school usual approach to explain their understanding of the properties of non-electrolytes; for example: 'Substance Y could be a covalent compound' or 'not having the freely moving ions to conduct electricity', even though the Chi-squared value presented above was not significant. It is also observed that students in the experimental class were able to explain the nature and properties of non-electrolytes better than the baseline class, as stated below:

(Experimental class)

"This is because white powder $\mathrm{Y}$ is a covalent compound that make it cannot conduct electricity. Covalent compound cannot conduct electricity in any state" [Exp-q]

"Because the white powder $\mathrm{Y}$ is a covalent compound which cannot conduct electricity in any state, white powder $\mathrm{Y}$ is not an electrolyte“ [Exp-u]

(Baseline class)

"There are no ions in substance Y, it's covalent compound, substance $\mathrm{Y}$ is not an electrolyte" [Bl-h]

"It is not an electrolyte" [B1-r] 


\section{Students' Conceptual Understanding for Item 1e}

\section{Responses referring to definition of 'electrolyte'}

For item 1e in Table 2, there was a significant difference between the number of correct responses of experiment and comparison classes relating to define the meaning of electrolyte $\left(\chi^{2}=4.95, \mathrm{df}=1, \rho=0.026\right)$. The critical value of Chisquared for $\mathrm{df}=1$ and $\alpha=0.05$ was 3.84. The obtained value of $\chi^{2}=4.95$ from Table 2 was slightly larger than the critical value of $\chi^{2}=3.84$. Also, the $\rho$ value of 0.026 was smaller than $\alpha=0.05$, thus the obtained Chi-squared value was significant; meaning that the difference between the classes was significant at the 5\% level. As there was one cell that has less count than 5, Fisher's Exact Test was applied. Similar findings were found in Fisher's Exact Test. The resulting $\rho$ using Fisher's exact test was 0.030 which was smaller than $\alpha=0.05$, and similar with the results from above and indicate that the Chi-squared value was significant.

In this item, there are $40.5 \%$ students in the experimental group were able to answer correctly, compared to only $14.8 \%$ in the comparison class and the result suggests that students following the teaching sequence were $25.7 \%$ more likely than students from the baseline class to define the meaning of electrolyte. However, the results were not significant enough to show the differences in the achievement in these two classes.

\section{Classroom Discourse}

As for the second objective, which is to examine the experimental students' conceptual understanding in of some aspects of electrochemistry after the teacher had utilised the design tool (communicative approach), the excepts below are presented according to the types of classroom discourse in the lesson that was related to items a-e above. The following are excerpts from teacher's demonstration of a simple circuit, and it was compared with an electrolytic cell.

Teacher: Looking at this circuit, which do you think will light up? [*Interactive/ Dialogic Discourse] 


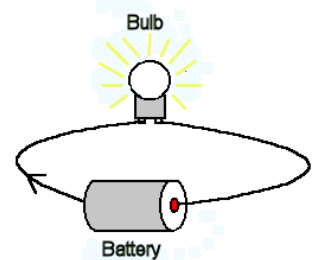

Circuit A

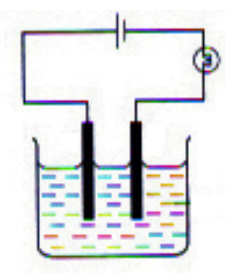

Circuit B

Students: Circuit A

Teacher: 'Experience tells us that metals are good conductors but what about molten/liquid substances? [*Interactive/Dialogic Discourse]

Students: (Silent)

Teacher: (After the electrolytic cell was set up). You can see the bulb lights up, what is your conclusion here? [*Interactive/ Dialogic Discourse]

Students: It has electricity/ The electrons are in the solution (Mixed responses)

Teacher: The ions are in the solution, not the electron [*NonInteractive/Dialogic Discourse]

Teacher: You can see the solution can conduct electricity, so what do you called it? [*Interactive/Authoritative Discourse]

Student A: conductive solute?

Teacher: Close. [*Non-interactive/Dialogic Discourse]

Teacher: What is the term of this copper sulphate solution? This copper sulphate solution can conduct electricity, what is your conclusion? [*Interactive/Authoritative Discourse]

Students: It has ionic bond/ It is an electrolyte (and some mixed responses) 
Teacher: Good, it is an electrolyte. This copper sulphate is an electrolyte. So what is the meaning of electrolyte [*Interactive/ Authoritative Discourse]

Students: Electrolyte can produce electricity (mixed responses)

Teacher: Electrolyte is actually substance which can conduct electricity in aqueous or molten state. [*Non-Interactive/ Authoritative Discourse]

Below are excerpts for further discussion:

Teacher: Solid cannot conduct electricity, molten/aqueous solution can conduct electricity. So what is the difference here? Why copper sulphate solution can conduct electricity, but copper sulphate solid does not conduct electricity? So what is the reason? What's the difference between solid and aqueous? [*Interactive/ Authoritative Discourse]

Students: (mixed responses)

Teacher: What's the difference between solid and aqueous? Which one does not have freely moving ion? Solid copper sulphate does not have freely moving ion, in the copper sulphate solution it has freely moving ion which is copper ion and sulphate ion. Can anyone tell me why only in copper sulphate solution, the freely moving ions exist? [*Interactive/Dialogic Discourse]

Students: The solution has positive and negative ions (and some mixed responses)

Teacher: We have already discussed the structure of solid in chemical bonding. What is your idea about it?

Student B: In solid the ions are in fixed position.

Teacher: Good. (repeats student's answer and continues). Between these positive and negative ions, it is attracted through the ionic force/bond, once you dilute it into the water, what happens? The positive and negative ions can move freely. Once 
it is freely moving, it can conduct electricity. [*Non-Interactive/ Authoritative Discourse]

From the above excerpts, it is observed that the teacher had used different kind of discourses to assist students' responses. Interactive/dialogic discourse was used at the beginning of the classroom talk in order to elicit students' ideas; as well as to encourage students to talk. As the lesson progressed, the classroom discourses changed to non-interactive/dialogic, interactive/authoritative to and finally to non-interactive/authoritative. These kinds of patterns show that the ideas were presented by the teachers from general to a more specific content.

\section{DISCUSSION}

Item 1a-e in the post-diagnostic test were developed to investigate students' conceptual understanding about the nature and properties of electrolytes. These include having negative (anion) and positive (cation) ions, and only being able to conduct electricity when they are in an aqueous (1a) or molten state (1c) whilst not being able to do so when in a solid state (1b). The students' understanding of the properties of non-electrolytes (e.g. properties of covalent compound) was also investigated (1d). Finally, the students were required to define an electrolyte in the last question (1e). Overall, the responses in items 1a-1c suggest that students in the experimental group had achieved an understanding of electrolytes as having freely moving ions which, when in a molten or aqueous state, were able to conduct electricity. As a result, the students were able to identify the nature and properties of non-electrolytes (item 1d). In particular, from the definition provided by some students' responses (item 1e), the students had achieved an understanding that electrolytes can conduct electricity. When students defined the term "electrolyte", they had to mention that electrolyte can conduct electricity when it is in aqueous state and decomposed in the process; meaning that the ions involved have changed to different products. It is found that some of the definitions provided by students in both classes that were coded as "scientifically correct" were similar with the one in the textbook.

From the findings in the content area of nature of electrolytes, there were huge differences in the students' understanding for both classes about the nature or the property of electrolyte (except for item 1d), and the results show that students in the experimental class who had followed the designed teaching had performed better. It shows that students in the experimental class understood that the electrolytes consist of freely moving ions and were able to conduct electricity in molten and 
aqueous state, and decomposed in the process; while non-electrolyte substance like the covalent compound could not conduct electricity at any state.

The students in the baseline class had provided reasoning that is mostly inaccurate because the findings revealed that in all five items, the responses that were coded as "other" obtained more than $50 \%$ of percentages, in comparison to less than one third achievement for the 'scientifically correct' responses. As reported in the literature section, the students often think that the electrons are moving inside the electrolyte solution, and visualise the movements as a complete cycle, similar to a simple circuit. However, the students also think that, somehow, the ions in the solution are responsible for transporting the electrons. the findings have provided evidence that, following normal classroom teaching, the baseline group still experienced difficulty in generating explanations for the chemical events that occur in the electrolytic cell and the related features. Thus, it can be concluded that some of the taught contents focusing on electrolytes and non-electrolytes were somehow able to show the differences in the performance between students in the experimental and baseline classes regarding their understanding of the nature and property of electrolytes.

In the experimental class, the students had responded and participated in the activities, either communicated with the teacher or their peers. The teacher had provided a platform for discussions and had given the students the opportunity to talk in the classroom. From the responses, the teacher was able to determine whether the students had difficulty in the concept. This is where the gap in the zone of proximal development is narrowed or not (according to Vygotsky) when the students collaborate with the teacher and their peers. This is supported in a study by Amponsah and Ochonogor (2018) where they also report a design of the teaching strategy that draws upon theoretical insights into perspectives of social constructivism that can enhance students' collaborative skills with their peers and teacher. Hence, there is a significant difference in the experimental group for their achievement in chemistry.

The authoritative discourse is either interactive or non-interactive which is like the conventional or normal teaching method, where the teacher asks scientific question and then explain the theory or concept to the students. What made this study different was the addition of interactive/dialogic discourse, whereby the teacher could determine the differences of everyday language and the language of school science. This was where the learning demand tools played its part to show the gap between everyday language and the scientific language. Then, different dimensions of classroom discourses that were used in different situations and context could provide opportunity for the students to be more confident to elaborate 
their answers. Scott, Mortimer, et al. (2006) explain that some teachers may have difficulties to manage the dialogic talk because the teacher needs knowledge and skills in order to manage dialogic classroom interaction. Also, the dialogic talk is best to elicit student's conceptions, especially in the area that dissatisfy them (Morton, 2012). Thus, the teacher is required to know not just the content, but the nature of students' everyday thinking and difficulties related to that content, so as to ask productive questions. The teachers also need to understand that dialogic talk is not necessarily interactive because a teacher can expound different opinions in a non-interactive teaching.

Also, the findings by Kanadlı and Sağlam (2016) also support this study in which they have reported about the classroom discourse before and after the intervention using authoritative and dialogic discourses. They have found that after the intervention, the dialogic discourse had improved students' learning outcomes as it involved individual responses, the justifications of the ideas, creating alternative solutions and students' speaking time. Thus, the intervention focusing on the classroom discourse might have contributed to these differences in the achievement of the experimental class. The findings in this study also had provided some empirical evidence that many students have developed conceptual difficulties in this learning area and the results do not support any assumption that normal classroom teaching had provided essential support for students to generate detailed, factual explanations about the chemical event (phenomena).

Furthermore, the students in the experimental class were able to provide better descriptions of the scientific event in terms of the level of detail; for example, those students were able to connect macroscopic observations with sub-microscopic explanations, or with the symbolic entities. In comparison to the baseline class, it can be concluded that many students were not able to establish connections between these three levels of representations, as their explanations were short and lacked key features of the taught content. It can be said that the students who followed the normal way of teaching, did not demonstrate good conceptual understanding in the learning areas. This might be because the approaches used in normal classroom teaching did not provide enough support to establish the connections between these three levels of representation by using classroom discourse (although it could also be due to other factors as well) (Ahmad \& Lah, 2013). For example, when teaching the nature and properties of electrolytes, if the scientific ideas are presented to the students using the lecture style method without asking them questions, this may lead to students easily forgetting what they had been taught. It could also be that the teaching activities did not support the students' conceptual understanding, especially with regard to sub-microscopic entities. In the experimental class, the evidence from the findings showed that 
students had a good conceptual understanding of four out of five learning areas. Thus, it could be said that the teaching and learning which followed the designed teaching sequence was in some ways successful in assisting students to explain the chemical events that occur in the electrolytic cell, in addition to recognition of its related features. This topic of electrochemistry is commonly viewed as a difficult topic in chemistry, but the outcomes from the results of students' responses show that teaching and learning using the designed teaching sequence, to a certain extent, has the potential to be utilised as a tool in normal classroom teaching.

\section{CONCLUSION}

These findings have provided some evidence that there were differences in the students' performances in the post diagnostic test, hence, some of the key features of the teaching successfully achieved their aims as follows:

1. The learning demands and the classroom discourse addressed were able to enhance students' understanding of the nature and properties of electrolytes.

2. The students were able to relate different levels of understanding especially in the sub-microscopic entities.

3. The students were able to generate detailed explanations of the scientific event.

4. The designed activities (some if not all) were able to support the students' classroom discourse.

5. The sequences of the activities (some if not all) are able to promote students' conceptual understanding of the taught content.

The Leeds Model framework particularly draws upon theoretical insights into research and uses an evidence-informed approach when designing a teaching sequence. The design tools such as the communicative approach is underpinned by the social constructivist perspective on learning and the teacher plays a central role in introducing scientific ideas on the social plane of the classroom. Drawing from this, the effectiveness of the designed teaching sequence can be determined according to whether or not students in the experimental class had developed a better conceptual understanding after teaching in comparison to the baseline group in this study.

There were few implications of the study from the aspects of pedagogical content knowledge. The microscopic entities of chemistry topics often created difficulties 
in students' learning. From the notion of learning demand, the teacher was able to identify the gap between the students' everyday social language and the content of the school science. Thus, it was easier to focus on the students' difficulties in order to correct their conceptual understanding. Furthermore, the teaching and learning of chemistry utilising the classroom discourse had provided the opportunity for the students to talk science using the scientific language instead of ordinary language. The students in the experimental class were given the platform to have dialogues with their teacher and peers, and they were able to internalised their learning when they understood the concepts or theory being discussed. The teacher also utilised the types of classroom discourses that were suitable to be applied in appropriate situations. Finally, for future studies, the design tools can be used in this topics or other science topics focusing on students difficulties in symbolic entities; i.e. chemical equation and many other symbolic representations.

\section{ACKNOWLEDGEMENTS}

We would like to thank our main supervisor Professor John Leach and our late cosupervisor Phil Scott for unconditional support throughout this research.

\section{APPENDIX A}

\section{Item 1 for Post-Diagnostic Test}

1. Puan Alia has given Nora and her group a chemical substance, X. She asks them to conduct an experiment in electrolysis using aqueous $\mathrm{X}$, solid $\mathrm{X}$ and molten X. From their experiment, they obtain the following results:

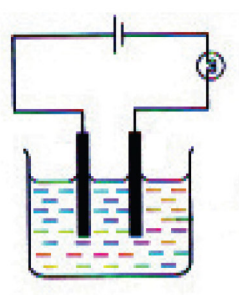

Aqueous X

Bulb lights up

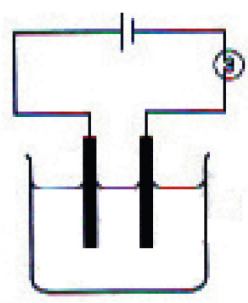

Solid X

Bulb does not light up

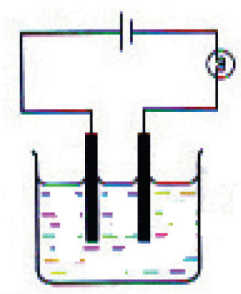

Molten X

Bulb lights up 
a. What is it about aqueous $\mathrm{X}$ which allows the bulb to light up?

b. What is it about solid $\mathrm{X}$ that STOPS the bulb from lighting?

c. What is about molten $\mathrm{X}$ which allows the bulb to light up?

d. Puan Alia then gives Nora and her friends a white powder Y and asks them to find out whether the bulb will light up with it. These are their findings:

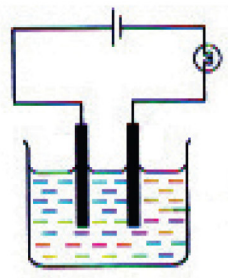

Aqueous X Bulb lights up

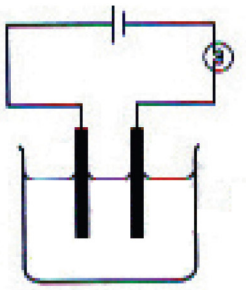

Solid X

Bulb does not light up

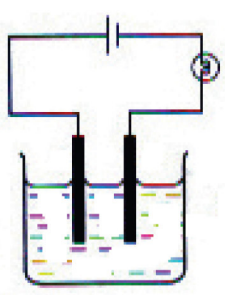

Molten X

Bulb lights up

Write down your ideas about why the bulb does NOT light up in any of these cases.

e. When the bulb lights up, we say that the liquid in the beaker is an electrolyte. What do you understand by the term electrolyte? 


\section{REFERENCES}

Acar, B., \& Tarhan, L. (2007). Effect of cooperative learning strategies on students' understanding of concepts in electrochemistry. International Journal of Science and Mathematics Education, 5(2), 349-373. https://doi.org/10.1007/s10763-0069046-7

Ahmad, N. J., \& Lah, Y. C. (2013). A designed teaching sequence as a tool to improve students' conceptual understanding of the conductivity in the electrolytic cell. Asian Social Science, 9(2), 298-304. https://doi.org/10.5539/ass.v9n2p298

Allsop, R. T., \& George, N. H. (1982). Redox in Nuffield advanced chemistry. Education in Chemistry, 19, 57-59.

Ametller, J., Leach, J., \& Scott, P. (2007). Using perspective on subject learning to inform the design of subject teaching: An example from science education. The Curriculum Journal, 18(2), 479-492. https://doi.org/10.1080/09585170701687928

Amponsah, K. D., \& Ochonogor, C. E. (2018). Facilitating conceptual change in students' comprehension of electrochemistry concepts through collaborative teaching strategy. American Journal of Educational Research, 6(6), 596-601.

Bakhtin, M. (1934). Discourse in the novel. Literary Theory: An Anthology, 2, 674-685.

Bakhtin, M. M. (1981). The dialogic imagination: Four essays. In M. Holquist (Eds.). Austin, TX: University of Texas Press.

Brandriet, A. R., \& Bretz, S. L. (2014). The development of the redox concept inventory as a measure of students' symbolic and particulate redox understandings and confidence. Journal of Chemical Education, 91(8), 1132-1144. https://doi. org/10.1021/ed500051n

Buty, C., Tiberghien, A., \& Le Maréchal, J-FL. (2004). Learning hypotheses and an associated tool to design and to analyse teaching-learning sequence. International Journal of Science Education, 26(5), 579-604. https://doi.org/10.1080/0950069 0310001614735

Cazden, C. B. (2001). The language of learning and teaching. Portsmouth, NH: Heinemann.

Cazden, C. B., \& Beck, S. W. (2003). Classroom discourse. In C. Graesser, M. A. Gernbascher, \& S. R. Goldman (Eds.), Handbook of Discourse Processes (pp. 165-197). Mahwah, NJ: Lawrence Erlbaum Associates.

Creswell, J. W. (2015). A concise introduction to mixed methods research. Thousand Oaks, CA: Sage publications.

De Jong, O., Acampo, J., \& Verdonk, A. (1995). Problems in teaching the topic of redox reactions: actions and conceptions of chemistry teachers. Journal of Research in Science Teaching, 32(10), 1097-1110. https://doi.org/10.1002/tea.3660321008

Doymus, K., Karacop, A., \& Simsek, U. (2010). Effects of jigsaw and animation techniques on students' understanding of concepts and subjects in electrochemistry. Educational Technology Research and Development, 58(6), 671-691. https://doi. org/10.1007/s11423-010-9157-2

Driver, R., Asoko, H., Leach, J., Mortimer, E., \& Scott, P. (1994). Constructing scientific knowledge in the classroom. Educational Researcher, 23(7), 5-12. https://doi. org/10.3102/0013189X023007005 
Driver, R., \& Easley, J. (1978). Pupils and paradigms: A review of literature related to concept development in adolescent science students. Studies in Science Education, 5, 61-84. https://doi.org/10.1080/03057267808559857

Forman, E. A., \& Kraker, M. J. (1985). The social origins of logic: The contributions of Piaget and Vygotsky. New Directions for Child and Adolescent Development, 1985(29), 23-39. https://doi.org/10.1002/cd.23219852904

Garnett, P. J., Garnett, P. J., \& Hackling, M. (1995). Students' alternative conceptions in chemistry: a review of research and implications for teaching and learning. Studies in Science Education, 25, 69-95. https://doi.org/10.1080/03057269508560050

Garnett, P. J., Garnett, P. J., \& Treagust, D. F. (1990). Implications of research on students' understanding of electrochemistry for improving science curricula and classroom practise. International Journal of Science Education, 12(2), 147-156. https://doi. org/10.1080/0950069900120203

Garnett, P. J., \& Treagust, D. F. (1992a). Conceptual difficulties experienced by senior high school students of electrochemistry: Electric circuits and oxidation-reduction equations. Journal of Research in Science Teaching, 29(2), 121-142. https://doi. org/10.1002/tea.3660290204

Garnett, P. J., \& Treagust, D. F. (1992b). Conceptual difficulties experienced by senior high school students of electrochemistry: Electrochemical (galvanic) and electrolytic cells. Journal of Research in Science Teaching, 29(10), 1079-1099. https://doi. org/10.1002/tea.3660291006

Harrison, A. G., \& Treagust, D. F. (1998). Modelling in science lessons: Are there better ways to learn with models? School Science and Mathematics, 98(8), 420-429. https://doi.org/10.1111/j.1949-8594.1998.tb17434.x

Hawkins, I., \& Phelps, A. J. (2013). Virtual laboratory vs. traditional laboratory: Which is more effective for teaching electrochemistry? Chemistry Education Research and Practice, 14(4), 516-523. https://doi.org/10.1039/C3RP00070B

Huddle, P. A., White, M. D., \& Rogers, F. (2000). Using a teaching model to correct known misconceptions in electrochemistry. Journal of Chemical Education, 77(1), 104-110. https://doi.org/10.1021/ed077p104

Iksan, Z. H., \& Daniel, E. (2015). Emerging model of questioning through the process of teaching and learning electrochemistry. International Education Studies, 8(10), 137-149. https://doi.org/10.5539/ies.v8n10p137

Jones, M. C. (1998). Language obsolescence and revitalization: Linguistic change in two sociolinguistically contrasting welsh communities. Oxford: Oxford University Press.

Kabapinar, F. M. (2009). Multi-frame illustrations: A molecular visual strategy in learning and teaching chemistry concepts. Australian Journal of Education in Chemistry, 69, 11-16.

Kabapinar, F., Leach, J., \& Scott, P. (2004). The design and evaluation of a teachinglearning sequence addressing the solubility concept with Turkish secondary school students. International Journal of Science Education, 26(5), 635-652. https://doi.org/10.1080/09500690310001614000 
Kanadlı, S., \& Sağlam, Y. (2016). Investigating the effectiveness of a professional development program designed to improve science teachers' classroom discourse. International Online Journal of Educational Sciences, 8(3), 97-112. https://doi. org/10.15345/iojes.2016.03.010

Leach, J., \& Scott, P. (2002). Designing and evaluating science teaching sequences: an approach drawing upon the concept of learning demand and a social constructivist perspective on learning. Studies in Science Education, 38, 115-142. https://doi. org/10.1080/03057260208560189

Leach, J. \& Scott, P. (2003). Individual and sociocultural perspectives on learning in science education. Science Education, 12, 91-113. https://doi. org/10.1023/A:1022665519862

Leach, J., \& Scott, P. (2008). Teaching for conceptual understanding: An approach drawing on individual and sociocultural perspectives. In S. Vosniadou (Ed.), International handbook of research on conceptual change (pp. 647-675). London: Routledge.

Leach, J., Scott, P., Ametller, J., Hind, A., \& Lewis, J. (2006). Implementing and evaluating teaching interventions. In R. Millar, J. Leach, \& M. Ratcliffe (Eds.), Improving subject teaching: Lessons from research in science education (pp. 79-99). London: Taylor and Francis.

Leach, J., Ametller, J., \& Scott, P. (2010). Establishing and communicating knowledge about teaching and learning scientific content: The role of design briefs. In K. Kortland, \& K. Klaasen (Eds.), Designing theory-based teaching-learning sequences for science education (pp. 7-36). Utrecht, NL: CDBeta Press

Lee, O., Quinn, H., \& Valdés, G. (2013). Science and language for English language learners in relation to Next Generation Science Standards and with implications for Common Core State Standards for English language arts and mathematics. Educational Researcher, 42(4), 223-233. https://doi. org/10.3102/0013189X13480524

Lemke, J. L. (1990). Talking science: Language, learning, and values. NJ: Ablex Publishing Corporation.

Lewis, E. B., Baker, D. R., \& Helding, B. A. (2015). Science teaching reform through professional development: Teachers' use of a scientific classroom discourse community model. Science Education, 99(5), 896-931. https://doi.org/10.1002/ sce. 21170

Marais, A. F. (2011). Overcoming conceptual difficulties in first-year chemistry students by applying concrete teaching tools. South African Journal of Chemistry, 64(1), $151-157$.

Michaels, S., \& O’Connor, C. (2015). Conceptualizing talk moves as tools: Professional development approaches for academically productive discussion. Socializing intelligence through talk and dialogue (e-book), 347-362. https://doi. org/10.3102/978-0-935302-43-1_27

Mercer, N., \& Dawes, L. (2014). The study of talk between teachers and students, from the 1970s until the 2010s. Oxford Review of Education, 40(4), 430-445. https://doi. org/10.1080/03054985.2014.934087

Mortimer, E., \& Scott, P. (2003). Meaning making in secondary science classrooms. UK: McGraw-Hill Education. 
Morton, T. (2012). Classroom talk, conceptual change and teacher reflection in bilingual science teaching. Teaching and Teacher Education, 28(1), 101-110. https://doi. org/10.1016/j.tate.2011.07.006

Ogude, A. N., \& Bradley, J. D. (1994). Ionic conduction and electrical neutrality in operating electrochemical cells: Pre-college and college student interpretations. Journal of Chemical Education, 71(1), 29-34. https://doi.org/10.1021/ed071p29

Onder, İ. (2017). The effect of conceptual change texts supplemented instruction on students' achievement in electrochemistry. International Online Journal of Educational Sciences, 9(4), 969-975. https://doi.org/10.15345/iojes.2017.04.006

Özmen, H. (2007). The effectiveness of conceptual change texts in remediating high school students' alternative conceptions concerning chemical equilibrium. Asia Pacific Education Review, 8(3), 413-425. https://doi.org/10.1007/BF03026470

Posner, G. J., Strike, K. A., Hewson, P. W., \& Gertzog, W. A. (1982). Accommodation of a scientific conception: Toward a theory of conceptual change. Science Education, 66(2), 211-227. https://doi.org/10.1002/sce.3730660207

Ringnes, V. (1995). Oxidation-reduction-learning difficulties and choice of redox models. School Science Review, 77, 74-77.

Rollnick, M., \& Mavhunga, E. (2014). PCK of teaching electrochemistry in chemistry teachers: A case in Johannesburg, Gauteng Province, South Africa. Educación Química, 25(3), 354-362. https://doi.org/10.1016/S0187-893X(14)70551-8

Rosenthal, D. P., \& Sanger, M. J. (2012). Student misinterpretations and misconceptions based on their explanations of two computer animations of varying complexity depicting the same oxidation-reduction reaction. Chemistry Education Research and Practice, 13(4), 471-483. https://doi.org/10.1039/C2RP20048A

Salloum, S., \& BouJaoude, S. (2019). The use of triadic dialogue in the science classroom: A teacher negotiating conceptual learning with teaching to the test. Research in Science Education, 49(3), 829-857. https://doi.org/10.1007/s11165-017-9640-4

Schmidt, H. J. (1991). A label as a hidden persuader: chemists' neutralization concept. International Journal of Science Education, 13(4), 459-471. https://doi. org/10.1080/0950069910130409

Scott, P., Leach, J., Hind, A., \& Lewis, J. (2006). Designing research evidence informed teaching interventions. In R. Millar, J. Leach, \& M. Ratcliffe (Eds.), Improving subject teaching: Lessons from research in science education (pp. 60-78). London: Taylor and Francis.

Scott, P. H., Mortimer, E. F., \& Aguiar, O. G. (2006). The tension between authoritative and dialogic discourse: A fundamental characteristic of meaning making interactions in high school science lessons. Science Education, 90(4), 605-631. https://doi. org/10.1002/sce.20131

Schegloff, E. A. (1978). On some questions and ambiguities in conversation. In W. U. Dressler (Ed.), Current trends in textlinguistics (Vol. 2, pp. 81-102). Berlin and New York: Walter de Gruyter. https://doi.org/10.1515/9783110853759.81

Schunk, D. H. (2000). Learning theories: An educational perspective (3rd ed.). Upper Saddle River, NJ: Merrill/Prentice Hall. 
Shemwell, J. T., \& Furtak, E. M. (2010). Science classroom discussion as scientific argumentation: A study of conceptually rich (and poor) student talk. Educational Assessment, 15(3-4), 222-250. https://doi.org/10.1080/10627197.2010.530563

Silverman, D. (1997). The logics of qualitative research. In G. Miller, \& R. Dingwall (Eds.), Context and method in qualitative research (pp. 12-25). London: Sage Publications.

Su, K. D. (2018). Enhancing students' corresponding reasoning of cognitive performances by animated Concept mapping in electrochemistry. Journal of Baltic Science Education, 17(4), 662-673.

Tobin, K. (1993). Referents for making sense of science teaching. International Journal of Science Education, 15(3), 241-254. https://doi.org/10.1080/0950069930150302

Tytler, R., \& Aranda, G. (2015). Expert teachers' discursive moves in science classroom interactive talk. International Journal of Science and Mathematics Education, 13(2), 425-446. https://doi.org/10.1007/s10763-015-9617-6

Vygotsky, L. S. (1978). Mind in society. Cambridge, MA: Harvard University Press.

Wertsch, J., \& Tulviste, P. (1992). L. S. Vygotsky and developmental psychology. Developmental Psychology, 28, 548-557. https://doi.org/10.1037/00121649.28 .4 .548

Wertsch, J. V. (1985). Vygotsky and the social formation of mind. Harvard: Harvard University Press. 